\title{
Further Evidence of Mutational Heterogeneity of the XPC Gene in Tunisian Families: A Spectrum of Private and Ethnic Specific Mutations
}

\author{
Mariem Ben Rekaya, ${ }^{1}$ Manel Jerbi, ${ }^{1}$ Olfa Messaoud, ${ }^{1}$ Ahlem Sabrine Ben Brick, \\ Mohamed Zghal, ${ }^{2}$ Chiraz Mbarek, ${ }^{3}$ Ashraf Chadli-Debbiche, ${ }^{3}$ Meriem Jones, ${ }^{1,2}$ \\ Mourad Mokni, ${ }^{4,5}$ Hamouda Boussen, ${ }^{1,6}$ Mohamed Samir Boubaker, ${ }^{1,7}$ Becima Fazaa, ${ }^{1,2}$ \\ Houda Yacoub-Youssef, ${ }^{1}$ and Sonia Abdelhak ${ }^{1}$ \\ ${ }^{1}$ Laboratoire de Génomique Biomédicale et Oncogénétique (LR 11 IPT 05), Institut Pasteur de Tunis and Université de Tunis El Manar, \\ El Manar I, 2092 Tunis, Tunisia \\ ${ }^{2}$ Département de Dermatologie, Hôpital Charles Nicolle de Tunis, 1006 Tunis, Tunisia \\ ${ }^{3}$ Service d'ORL et de Chirurgie Cervico-Faciale, Hôpital Habib Thameur, 1008 Tunis, Tunisia \\ ${ }^{4}$ Unité de recherche "Troubles Héréditaires de la Kératinisation" UR 24/04, Hôpital La Rabta de Tunis, 1007 Tunis, Tunisia \\ ${ }^{5}$ Département de Dermatologie, Hôpital La Rabta de Tunis, 1007 Tunis, Tunisia \\ ${ }^{6}$ Département d'Oncologie Médicale, Hôpital Abderrahman Mami, 2080 Ariana, Tunisia \\ ${ }^{7}$ Laboratoire d'Anatomie Pathologique Humaine et Expérimentale, Institut Pasteur de Tunis, 1002 Tunis, Tunisia
}

Correspondence should be addressed to Mariem Ben Rekaya; rekayamariem@yahoo.fr

Received 3 April 2013; Revised 27 May 2013; Accepted 2 July 2013

Academic Editor: Sanford I. Bernstein

Copyright (C) 2013 Mariem Ben Rekaya et al. This is an open access article distributed under the Creative Commons Attribution License, which permits unrestricted use, distribution, and reproduction in any medium, provided the original work is properly cited.

\begin{abstract}
Xeroderma Pigmentosum (XP) is a rare recessive autosomal cancer prone disease, characterized by UV hypersensitivity and early appearance of cutaneous and ocular malignancies. We investigated four unrelated patients suspected to be XP-C. To confirm linkage to $X P C$ gene, genotyping and direct sequencing of $X P C$ gene were performed. Pathogenic effect of novel mutations was confirmed by reverse Transciptase PCR. Mutation screening revealed the presence of two novel mutations g.18246G $>A$ and g.18810G $>$ T in the XPC gene (NG_011763.1). The first is present in one patient XP50NEF, but the second is present in three unrelated patients (XP16KEB, XP28SFA, and XP45GB). These 3 patients are from three different cities of Southern Tunisia and bear the same haplotype, suggesting a founder effect. Reverse Transciptase PCR revealed the absence of the XPC mRNA. In Tunisia, as observed in an other severe genodermatosis, the mutational spectrum of XP-C group seems to be homogeneous with some clusters of heterogeneity that should be taken into account to improve molecular diagnosis of this disease.
\end{abstract}

\section{Introduction}

Xeroderma Pigmentosum (XP) is a rare monogenic autosomal recessive DNA repair disorder. It is characterized by an extreme sun sensitivity especially to Ultra Violet Radiation (UVR) that induces cutaneous and mucous membranes cancers of the eyes and mouth [1].

$\mathrm{XP}$ is the archetype of an expanding family of Nucleotide Excision Repair (NER) diseases where XP cells were found to have defects in seven of the NER pathway proteins (XPA to $\mathrm{XPG})[2]$.

In addition, an XP variant group (XP-V) involving a DNA translesional synthesis (TLS) and polymerase Pol eta (POLH) has also been described [3]. XP-V patients have a normal NER level, but their cells are hypermutable following UVR.

This disease is rare in the United States and Europe $(1 / 100000)$ [4] but relatively more frequent in Japan (1/ 22000) [5] and in North Africa [6] especially in Tunisia 
with $1 / 10000$. This high frequency might be due to the high rate of consanguinity in Tunisia (29.8\%) especially among families with autosomal recessive diseases $(78.4 \%)$ [7] and to founder effects reported in XPC [8], XPA [9], and $X P V$ genes (unpublished data) in the Tunisian population.

The XPC gene plays an important role in the early step of Global Genome Repair pathway (GGR). XPC protein is involved in the recognition of the damaged DNA via a complex composed by HR23B-XPC-CEN during GGR pathway [10]. Currently, 46 mutations have been described in this gene. The most common are deletions (36.9\%), substitutions (34.7\%), splicing (19.5\%), and insertions (8.6\%). Splice site mutations have been described, in introns $2,5,1,8,9$, and 11 [11].

Molecular investigations of the XP-C group showed that it is the major group among the five North African countries called the Maghreb $[6,8,12,13]$. Indeed, among the studied patients, about $87 \%$ of them shared the recurrent founder mutation c.1643_1644delTG (p.V548AlafsX25) [6]. This was confirmed by its high carriers frequency estimated to be $1 / 250$ in Morocco [12]. Having a homogeneous mutational spectrum for the XPC gene has greatly simplified the molecular diagnosis of XP-C in the region $[6,8,13]$. Furthermore, two other private mutations have been recently reported in North African patients [6]. In this study, we have further enlarged the mutational spectrum of the XPC gene with the identification of two novel gene alterations.

\section{Patients and Methods}

2.1. Patients. This study was performed on 4 consanguineous Tunisian families originating from Southern Tunisia and encompassing 15 individuals. Among them, 4 patients (2 males and 2 females) were suspected to be XP-C. The age of the investigated XP patients is heterogeneous (ranging from 7 to 22 years). Consanguinity was confirmed in all families.

2.2. Methods. Informed consent was obtained from all available family members or the parents of minor children. Families were interviewed using structured questionnaire to collect information about family history, consanguinity, affected members, and associated diseases. This protocol was approved by the Ethics Committee of the Pasteur Institute of Tunis.

2.2.1. DNA Extraction. DNA was isolated from peripheral blood leukocyte using salting out method [14] or Qiagen kit DNA extraction. Genotyping for 14 available individuals was determined using 3 microsatellite markers spanning a $1.43 \mathrm{Mb}$ interval that overlaps the XPC gene region (D3S3602, D3S1585, and D3S3613). Microsatellite markers were selected from the genetic maps available on NCBI browsers and the CEPH genotype database (http://www.cephb.fr/en/cephdb/) on the basis of their heterozygosity percentage and closeness to the XPC gene. Genomic DNA amplification was carried using specific primers (Table 2), and the fragments were amplified in a volume of $25 \mu \mathrm{L}$ containing $10 \mathrm{ng}$ of DNA,
10X PCR buffer, $0.2 \mathrm{mM}$ of each dNTP, $1.5 \mathrm{~mL}$ of $\mathrm{MgCl}_{2}$, $0.5 \mu \mathrm{M}$ of one of each primer, and $0.5 \mathrm{U}$ Amplitaq DNA polymerase (Invitrogen). Fluorescent PCR products were run on the Genetic Analyzer and analyzed using the Gene Mapper software.

2.2.2. Mutation Analysis. Exons 4 to 16 and their flanking regions were amplified from genomic DNA. Primer pairs were generated using Primer 3 http://frodo.wi.mit.edu/ and UCSC In Silico-PCR (http://genome.ucsc.edu/cgi-bin/hgPcr) (Table 3). PCR conditions used in our laboratory were previously described [8]. PCR products were directly sequenced using the ABI 3130 Genetic Analyzer. Nomenclature mutations were performed using the NG_011763.1 according to the HGVS version 2.0 (Mutalyzer 2.0.beta-26).

2.2.3. RNA Extraction and RT-PCR. In order to assess the impact of the identified mutations at the RNA level, total RNA was isolated from leukocytes using trizol-chloroform purification and isopropanol precipitation [15]. The only biological material that was available for RNA extraction for the XP45GA and XP50NEF patients was $1 \mathrm{~mL}$ of whole blood frozen in $10 \%$ Dimethyl Sulfoxide (DMSO) at $-80^{\circ} \mathrm{C}, 4$ years ago. RT-PCR of the control was performed on a fresh blood sample for a healthy volunteer.

The RNA $(0.4 \mu \mathrm{g})$ was reverse transcribed in a final volume of $20 \mu \mathrm{L}$ using the reverse transcriptase (Ref 1785826, Roche), OligodT (Ref 27-7858-01, Pharmacia), Buffer 1X (Ref 1785826, Roche), dNTP $1 \mathrm{mM}$ (Invitrogen), and the Rnase inhibitor $40 \mathrm{U} / \mu \mathrm{L}$ (1785826, Roche). The cDNA corresponding to the XPC gene was amplified using a new couple of primers (Table 2). In order to evaluate the quality of the cDNA amplification, a PCR for a housekeeping gene GAPDH was conducted using primers showed in Table 2 (Figure 3 ).

\section{Results}

3.1. Clinical Findings. All investigated patients had the classical skin abnormalities of XP including xerosis, skin atrophy, and abnormal pigmentation with no neurological abnormalities. In our study, XP symptoms began at a mean age of 39 months. Skin hyperphotosensitivity from UVR was present in all patients. The specific poikilodermic pigmentation pattern (association between achromic spots and poorly limited pigmented maculae) covered the majority of the sunexposed areas. The mean age at onset of the first skin cancer was 12 years (range 8 to 17). Basal Cell Carcinoma (BCC) occurred in 3 patients (XP28SFA, XP45GB, and XP50NEF). Among them two patients (XP50NEF and XP45GB) developed melanoma (MM) and Spindle Cell Carcinoma (SCC) (Table 1).

In addition, patients XP45GB and XP28SFA developed, respectively, a thyroid cancer and a benign articular tumor of the knee (Table 1). For the patient XP45GB, clinical and ultrasound exams showed bilateral multinodular thyroid without hormonal dysfunction (normal rates of T4, T3, and TSH). After thyroidectomy, histological analysis confirmed thyroid carcinoma. No metastasis was found. 
TABLE 1: Microsatellite markers surrounding the XPC locus.

\begin{tabular}{|c|c|c|c|c|c|c|c|}
\hline $\begin{array}{l}\text { Microsatellites } \\
\text { markers }\end{array}$ & $\begin{array}{l}\text { Physical distance } \\
(\mathrm{pb})\end{array}$ & $\begin{array}{c}\text { Genetic } \\
\text { location } \\
(\mathrm{cM})\end{array}$ & Heterozygosity & $\begin{array}{c}\text { Number } \\
\text { of } \\
\text { alleles }\end{array}$ & Primers sequence & $\begin{array}{l}\text { Allele } \\
\text { size } \\
\text { range }\end{array}$ & Fluorescence \\
\hline D3S3602 & $13.926 .066-13.926 .191$ & 31.40 & $57.69 \%$ & 7 & $\begin{array}{l}\text { F: AAAATCCTAACCCAAAATGT } \\
\text { R: ATCAGAAAATAACAGAGGGC }\end{array}$ & $114-132$ & FAM \\
\hline D3S1585 & 13.941.728-13.941.855 & 33.00 & $57.14 \%$ & 8 & $\begin{array}{l}\text { F: TGCACGAGCCAGAAGT } \\
\text { R: TTGGACTGCTGAGGGG }\end{array}$ & $126-144$ & NED \\
\hline D3S3613 & $15.361 .998-15.362 .181$ & 35.70 & $78.57 \%$ & 8 & $\begin{array}{l}\text { F: CATCTATGTGGCAATCGG } \\
\text { R: CAGCATTTGTTGTAGGGACT }\end{array}$ & $172-208$ & FAM \\
\hline
\end{tabular}

TABLE 2: Sequence primers used for PCR amplification of XPC and GAPDH genes.

\begin{tabular}{|c|c|c|c|c|}
\hline & PCR & Primer Sense & Primer Anti-sense & $T_{m}{ }^{\circ} \mathrm{C}$ \\
\hline \multirow{14}{*}{ XPC } & Exon 4 & ATGCСТCAСTTCСТCСТTCC & CACTTTGATACTCAGTCCTGGTCCC & 55 \\
\hline & Exon 5 & GATTCACTGTCATCCGAGGAGAAG & CAAAGGCTCAGAGAGAGTAAGAAACTTG & 55 \\
\hline & Exon 6 & TGAAAGACAAGACCAAAACAAAAACAG & GACCTGAACCCAGCCTCTGAG & 55 \\
\hline & Exon 7 & СТСССТСTTTTTATTTTCTTGGCTG & GGTGCCTGTAGGCATTTGATAAAGC & 55 \\
\hline & Exon 8 & TTGAACAAGCACCATAACAAACAAC & TGCCCAAGTCTTCCCTAACACAG & 55 \\
\hline & Exon 9 & CCAGGGTGTCTTATAAAGAGG & CAAGGCCTTACCTCCAAG & 55 \\
\hline & Exon 10 & CCTTGGCTCCACCATCTGTTG & CCCTGTAACTGTTTTTCCCCTGC & 60 \\
\hline & Exon 11 & AGATTAGGGTTTGTAAGTGGACACATC & GGACTGGGAGGCTCATCATCAC & 55 \\
\hline & Exon 12 & CTGGTAGGTGTGTTCTGAGGGTTC & CGGTGTAGATTGGGCAGGTTC & 60 \\
\hline & Exon 13 & GGCAGCATCAGAAGGGCTCAG & AAATCCAGTGTAACATCCTGAAAATTG & 60 \\
\hline & Exon 14 & AGGCTGGATAGGGGCTTTCAC & CCTGCTGTATTCAGTGCTCGCTC & 60 \\
\hline & Exon 15 & CCACTAAAGATTTTGGAGTCAGTAACG & ACAGGGCTTGGGGCAGAAGAG & 55 \\
\hline & Exon 16 & CССTTGTCCTCCCAGAGTTACAC & ATGCTGCCTCAGTTTGCCTTC & 60 \\
\hline & cDNA & TTGAAGAACTTAGTGAGCCTGTG & GCTGGGTTGCCTTCTCCT & 60 \\
\hline GAPDH & cDNA & GAGTCAACGGATTTGGTCGT & TTGATT TTGGAGGGATCTCG & 60 \\
\hline
\end{tabular}

3.2. Genetic and Molecular Results. For molecular diagnosis, we first screened the recurrent founder mutation for all $\mathrm{XP}-\mathrm{C}$ suspected patients. Since this gene alteration has not been identified, linkage to the XPC gene was performed. Fourteen individuals were genotyped with 3 informative microsatellite markers. All XP-C patients showed homozygous genotypes for the D3S1585 marker. Three patients (XP16KEB, XP45GB, and XP28SFA) shared the same founder haplotype (126-130), respectively, for D3S3602 and D3S1585 markers (Figure 1), whereas patient XP50NEF presented a private haplotype (Figure 2). Therefore, sequencing of exons 4 to 16 was performed for all XP patients. Two novel variations were identified. The first one is a splicing mutation (g.18246G > A; c.779+1G >A) present at a homozygous state in patient XP50NEF. It likely abolishes the exon 6 splicing donor site as shown by the following bioinformatic tools: "BDGP" (http://www.fruitfly.org/seq_tools/splice.html) and "Human splicing finder mutation" (http://www.umd.be/HSF/). This mutation probably leads to a premature stop codon at position 260 that results in a truncated XPC protein (p.Trp260X). To note, this mutation is not present in the public dbSNP database (http://www.ncbi.nlm.nih.gov/snp). In addition, Mendelian inheritance of this mutation was confirmed (Figure 2).

The second mutation is a $\mathrm{G}$ to $\mathrm{T}$ substitution at position 14521 of the genomic DNA (g.18810G $>$ T; c.850G $>$ T) present at a homozygous state in (XP28SFA, XP16KEB, and XP45GB) patients. This founder mutation probably leads to a premature stop codon at position 284 of XPC protein (p284X).

RT-PCR results showed the absence of XPC mRNA for (XP50NEF and XP45GB) patients having, respectively, the c. $779+1 G>A$ and c.850G $>$ T mutations, although we succeeded the amplification of the GAPDH cDNA (Figure 3).

\section{Discussion}

$\mathrm{XP}$ is a highly heterogeneous disease at clinical and genetic levels. XP-A and XP-C are the most frequent groups, especially in Southern Europe and North Africa [4, 6]. Previous studies have shown that all XP-C Tunisian patients shared the same mutation c.1643_1644delTG (p.V548AlafsX25) affecting exon 9 [8]. We report here two novel mutations in XP$\mathrm{C}$ Tunisian patients. All investigated patients have classical symptoms of XP with varying severity. BCC occurred in three among four patients confirming that it is the most frequent skin cancer observed in XP patients [16]. Among the studied patients, two (XP28SFA and XP16KEB) have benefited from a complete UVR protection thanks to the help of the patients support group "Helping Xeroderma Pigmentosum children” (http://www.xp-tunisie.org.tn/) (Table 1). Consequently, XP28SFA patient developed one BCC at the age 

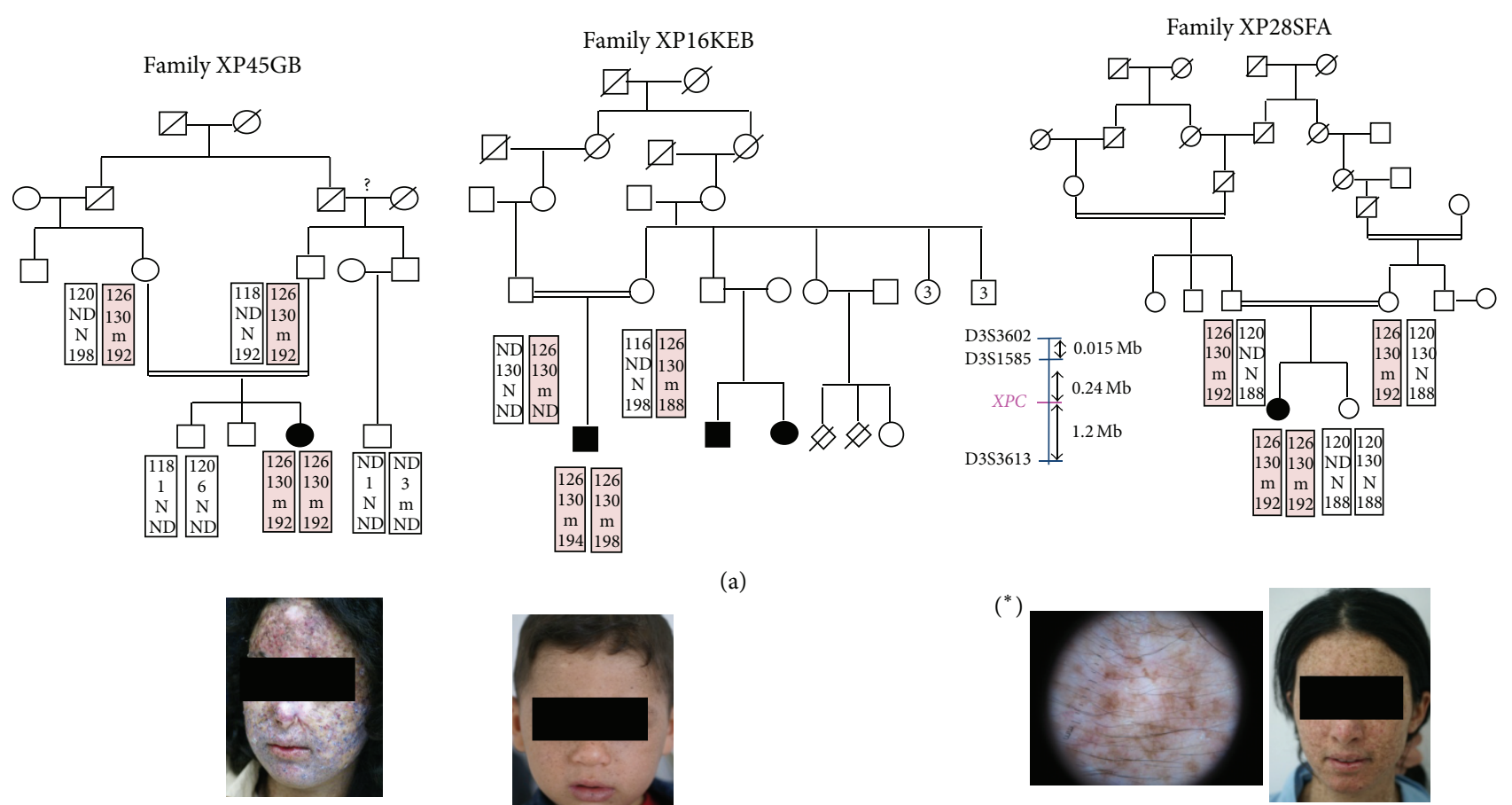

(a)
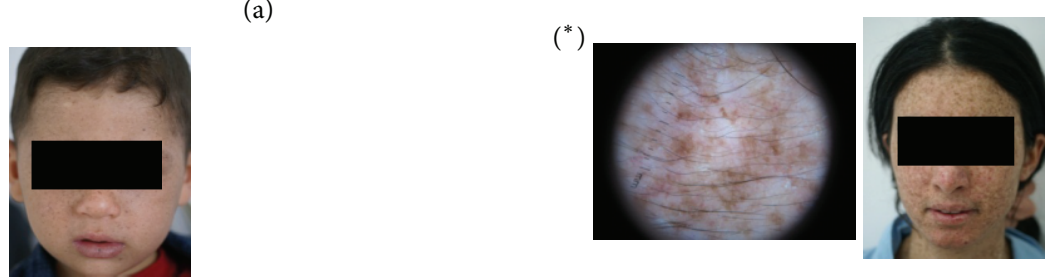

(b)

120

A C T A C A T T G T A A A G G

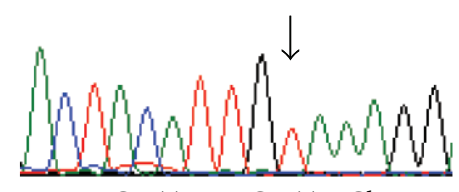

g.18810G > T; c.850G > T; p.Glu284X

(1)

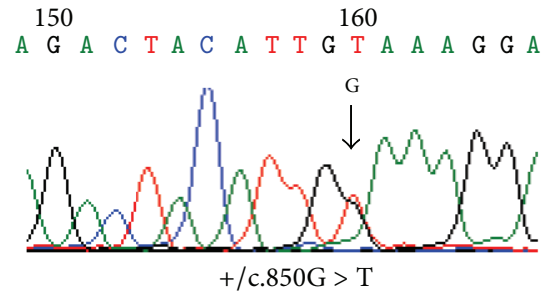

(2)
120
T G G A A A G G A G A T T T G C T A

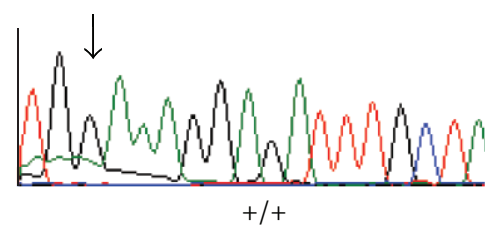

(3)

(c)

FIGURE 1: (a) Pedigrees and haplotype analysis for the XP45GB, XP16KEB, and XP28SFA patients. The disease haplotype is indicated by shading. m, mutant allele; N, normal allele; ND, not determined. (b) Clinical photographs of investigated XP-C patients showing clinical variability despite genetic homogeneity. $\left({ }^{*}\right)$ Dermoscopic examination of XP28SFA patient showing polymorphic pigmented and achromic macula. (c) Genomic DNA sequence showing the G to T substitution in the exon 7 of the XPC gene in homozygous state (1) or in a heterozygous parent (2) which is compared to the wild-type sequence of a control (3).

of 17 years that is higher than the median age at onset of Non-Melanoma Skin Cancer (NMSC) in XP patients (9 years) [17]. Regarding XP16KEB patient, until the age of 7 years, he did not develop skin cancer. Melanoma occurred in two patients XP50NEF and XP45GB at the age of 17 years which is lower than the median age at onset of melanoma (22 years) in XP patients [17]. Regarding the XP45 GB patient, she was treated by retinoid at age 13 during a period of 3 years; after that the number of NMSC was increased. At age 16, she developed nodular thyroid. During the last consultation at age 17 , we discovered that the patient showed resistance to cisplatin chemotherapy used to treat multiple spindlecell carcinomas of the face. The precise role of retinoid in cancer inhibition has not been clearly demonstrated in XP patients. Recent studies have shown a key role of GGR pathway especially XPC protein to repair cisplatin and eventually UV lesions in melanomagenesis [18, 19]; further investigation possibly will explain the resistance of $\mathrm{XP}-\mathrm{C}$ patient to chemotherapy.

In addition to skin cancers, XP45GB developed a thyroid cancer. She was not treated by X-rays or radiotherapy. According to the genetic questionnaire filled by the interview of the parents, there is no other cancer case in the family. Generally, XP patients can rarely develop internal cancer because they die at an early age. A recent study demonstrated that multinodular thyroid was the most frequent kind of internal tumor in XP-C patients [16], while adenocarcinoma of the thyroid was reported in only one 18-year-old XP$C$ patient [20]. This might be due to the accumulation of oxidative damage in the thyroid [21].

In the absence of the recurrent mutation XPC c.1643 1644 delTG, genotyping and haplotype analysis showed that 


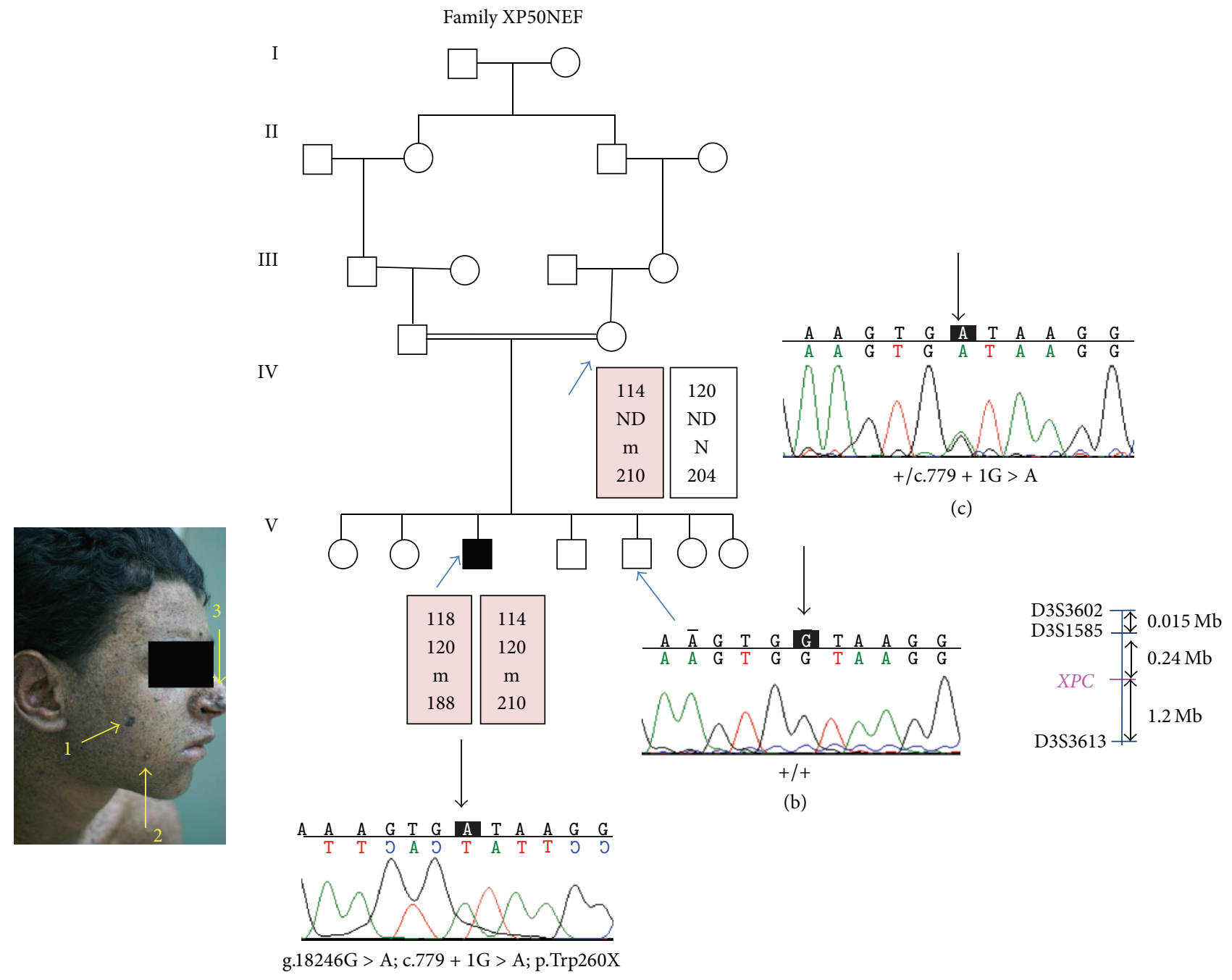

(a)

FIgURE 2: (a) Pedigree and haplotype analysis for the XP50NEF family. The disease haplotype is indicated by shading. $\mathrm{m}$, mutant allele; N, normal allele; ND, not determined. (b) Clinical photograph of XP50NEF patient (1: melanoma; 2: angiogranuloma; 3: BCC). The sequence electropherogram of the sense strand in exon 6 of XPC gene showing the G>A substitution in homozygous state (a) in comparison with the wild type sequence (b) or in a heterozygous parent (c).

all XP-C patients are homozygous for the closest marker to XPC gene, D3S1585. Sequencing and mutation analysis confirmed the presence of the two novel mutations. Thus showing that the D3S1585 marker is the most informative marker.

In order to test the impact of the two identified mutations at the functional level, we performed an RT-PCR experiment for patients when RNA was available. For XP50NEF and XP45 GB patients, XPC mRNA was absent. The same result was obtained in XP-C patients bearing the recurrent mutation (c.1643_1644delTG) in exon 9. The presence of these mutations probably reduces transcription of the XPC gene or alters the stability of its mRNA which could be degraded by the NMD system (Nonsense Mediated mRNA Decay) [22].

Although the two patients XP45GA (having a nonsense mutation) and XP50NEF (having a splice site mutation) underwent a low UV protection and have the same age, the second patient XP50NEF had a milder phenotype than the first (Figures 1 and 2). A small amount of normally spliced mRNA of the XPA gene is sufficient to explain relatively mild clinical features of XP-A patients [23]. Previous study reported that XP-C patient with a splice site mutation has a very low level of normal XPC mRNA transcript (3\%) resulting in $29 \%$ of normal level of normal sized XPC protein [24]. For the XP50NEF patient, cell lines are not available to confirm the presence of a small amount of XPC mRNA isoforms.

Genetic counseling was performed for four related individuals. The sister of XP28SFA and the brother of XP45 GB were healthy with a homozygous genotype, whereas the cousin of XP45 GB and the brother of XP50NEF were healthy heterozygous carriers (Figure 1).

A recent study showed that in Tunisian patients among 174 genetic diseases with identified molecular defect, 73 $(41,9 \%)$ were founder mutations. For the majority of them, 
TABLE 3: Clinical features of the XP-C patients.

\begin{tabular}{|c|c|c|c|c|c|c|c|c|c|}
\hline \multirow[t]{2}{*}{$\begin{array}{l}\text { Patients } \\
\text { code }\end{array}$} & \multirow[t]{2}{*}{ Sex } & \multirow{2}{*}{$\begin{array}{c}\text { Age at first } \\
\text { consultation } \\
\text { (years) }\end{array}$} & \multirow[t]{2}{*}{$\begin{array}{l}\text { Age } \\
\text { (years) }\end{array}$} & \multirow{2}{*}{$\begin{array}{l}\text { City } \\
\text { geographic } \\
\text { origin }\end{array}$} & \multicolumn{3}{|c|}{$\begin{array}{l}\text { Age at onset of the first skin tumor } \\
\text { (years) (number) }\end{array}$} & \multirow{2}{*}{$\begin{array}{l}\text { Internal cancer (age at } \\
\text { onset) }\end{array}$} & \multirow[t]{2}{*}{$\begin{array}{l}\text { Protection } \\
\text { from UVR }\end{array}$} \\
\hline & & & & & $\mathrm{MM}$ & BCC & SCC & & \\
\hline XP16KEB & M & 2 & 7 & Kebelli & - & - & - & - & +++ \\
\hline XP28SFA & $\mathrm{F}$ & 3 & 21 & Sfax & - & $17(1)$ & - & $\begin{array}{l}\text { Benign articular } \\
\text { tumor of the knee (18) }\end{array}$ & +++ \\
\hline XP45GB & $\mathrm{F}$ & 2 & 18 & Gafsa & $17(1)$ & $8(>20)$ & $9(>10)$ & Thyroid cancer (16) & + \\
\hline XP50NEF & M & 6 & 22 & Nefta & $17(1)$ & $11(>5)$ & $17(1)$ & - & + \\
\hline
\end{tabular}

MM: melanoma; BCC: Basal Cell Carcinoma; SCC: Spino Cell Carcinoma; +++: high protection; +: low protection.

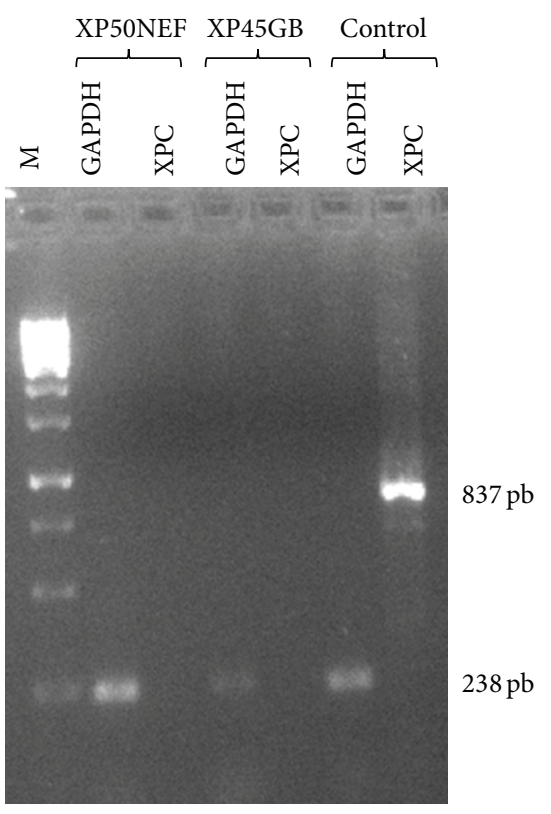

FIGURE 3: Agarose gel electrophoretic analysis of the RT-PCR showed the absence of the XPC cDNA amplification for XP50NEF and XP45GB patients compared to healthy control. The cDNA of the GAPDH gene was successfully amplified for all individuals. The variability of intensity of amplification between XP45GA patient and control is due to the quality of conservation of the blood sample. (M: $1 \mathrm{~kb}$ DNA ladder molecular size marker (GeneRuler)).

geographic distribution is limited to a region of the country [25]. A similar situation is observed in our study where the c.850G $>\mathrm{T}$ founder mutation seems to be restricted to the South of Tunisia. Knowing the disease features in a given population is important to offer a suitable management of the patients and their families [25]. As XP-C is the most common group in North Africa with a high morbidity and an early mortality, primary diagnosis is important. As XP$\mathrm{C}$ patients do not show neurological impairment, they could live a nearly normal life if they benefit from an early full protection against sunexposure. This is the case of patient XP28SFA who has been protected during early infancy and is now following "normal" university studies. But other clinical exams should be programed especially thyroid ultrasound for early detection of internal cancer. Since dermatological exam could not confirm exactly the XP group, specifically for young patients, molecular diagnosis is necessary to confirm clinical diagnosis and to propose genetic counseling.

The high frequency of the same founder mutations in patients from North Africa has greatly simplified the molecular diagnosis of XP syndrome in Maghreb region. Considering the efforts and costs required for the unscheduled DNA synthesis on cultured fibroblasts, we therefore suggest, for suspected XP-C patients without XPC-p.Val548AlafsX25 mutation, genotyping analysis to confirm linkage to XPC gene especially for consanguineous or endogamous families. If linkage to XPC gene is confirmed, the second founder mutation, c.850G $>\mathrm{T}$ in exon 7 , should be investigated. In the absence of this mutation, sequencing of exon 6 must be performed. This exon contains three different mutations (c.652delT, c.658C > T, and c.779+1G>A) described in North African patients. Cascade screening should be proposed to all the families in which an index case has an identified mutation $[26,27]$.

\section{Conclusion}

Our results show that private mutations, ethnic specific mutations, and recurrent founder mutations could explain the mutational heterogeneity of XP-C group in Tunisia. In addition, our findings provide a valuable tool for molecular diagnosis and carrier screening of this severe genodermatosis at the regional level where endogamy is still culturally favored.

\section{Conflict of Interests}

All authors declare that they have no conflict of interests.

\section{Authors' Contribution}

Mariem Ben Rekaya and Manel Jerbi contributed equally to this work.

\section{Acknowledgments}

The authors would like to thank the patients and their families as well as the patients' support group "Helping Xeroderma Pigmentosum children" (http://www.xp-tunisie.org.tn/) for their collaboration. This work was supported by the Tunisian 
Ministry of Higher Education and Scientific Research (Laboratory on Biomedical Genomics and Oncogenetics, LR 11 IPT 05) and the Tunisian Ministry of Public Health.

\section{References}

[1] J. J. Digiovanna and K. H. Kraemer, "Shining a light on xeroderma pigmentosum," Journal of Investigative Dermatology, vol. 132, no. 3, pp. 785-796, 2012.

[2] J. E. Cleaver, "Cancer in xeroderma pigmentosum and related disorders of DNA repair," Nature Reviews Cancer, vol. 5, no. 7, pp. 564-573, 2005.

[3] C. Masutani, R. Kusumoto, A. Yamada et al., "The XPV (xeroderma pigmentosum variant) gene encodes human DNA polymerase $\eta$," Nature, vol. 399, no. 6737, pp. 700-704, 1999.

[4] W. J. Kleijer, V. Laugel, M. Berneburg et al., "Incidence of DNA repair deficiency disorders in western Europe: xeroderma pigmentosum, Cockayne syndrome and trichothiodystrophy," DNA Repair, vol. 7, no. 5, pp. 744-750, 2008.

[5] Y. Hirai, Y. Kodama, S.-I. Moriwaki et al., "Heterozygous individuals bearing a founder mutation in the XPA DNA repair gene comprise nearly $1 \%$ of the Japanese population," Mutation Research, vol. 601, no. 1-2, pp. 171-178, 2006.

[6] N. Soufir, C. Ged, A. Bourillon et al., "A prevalent mutation with founder effect in xeroderma pigmentosum group $\mathrm{C}$ from north Africa," Journal of Investigative Dermatology, vol. 130, no. 6, pp. 1537-1542, 2010.

[7] N. Ben Halim, N. Ben Alaya Bouafif, L. Romdhane et al., "Consanguinity, endogamy, and genetic disorders in Tunisia," The Journal of Community Genetics, vol. 4, pp. 273-284, 2013.

[8] M. Ben Rekaya, O. Messaoud, F. Talmoudi et al., "High frequency of the V548A fs X572 XPC mutation in Tunisia: implication for molecular diagnosis," Journal of Human Genetics, vol. 54, no. 7, pp. 426-429, 2009.

[9] O. Messaoud, M. Ben Rekaya, W. Cherif et al., "Genetic homogeneity of mutational spectrum of group-A xeroderma pigmentosum in Tunisian patients," International Journal of Dermatology, vol. 49, no. 5, pp. 544-548, 2010.

[10] S. Bergink, W. Toussaint, M. S. Luijsterburg et al., "Recognition of DNA damage by XPC coincides with disruption of the XPCRAD23 complex," Journal of Cell Biology, vol. 196, no. 6, pp. 681688, 2012.

[11] F. Cartault, C. Nava, A.-C. Malbrunot et al., "A new XPC gene splicing mutation has lead to the highest worldwide prevalence of xeroderma pigmentosum in black Mahori patients," DNA Repair, vol. 10, no. 6, pp. 577-585, 2011.

[12] Y. Doubaj, F.-Z. Laarabi, S. Chafai Elalaoui, A. Barkat, and A. Sefiani, "Carrier frequency of the recurrent mutation c.16431644delTG in the XPC gene and birth prevalence of the xeroderma pigmentosum in Morocco," Journal of Dermatology, vol. 39, no. 4, pp. 382-384, 2012.

[13] M. A. Senhaji, O. Abidi, S. Nadifi et al., "c.1643_1644delTG XPC mutation is more frequent in Moroccan patients with xeroderma pigmentosum," Archives of Dermatological Research, vol. 305, pp. 53-57, 2013.

[14] S. A. Miller, D. D. Dykes, and H. F. Polesky, "A simple salting out procedure for extracting DNA from human nucleated cells," Nucleic Acids Research, vol. 16, no. 3, p. 1215, 1988.

[15] P. Chomczynski and N. Sacchi, "Single-step method of RNA isolation by acid guanidinium thiocyanate-phenol-chloroform extraction," Analytical Biochemistry, vol. 162, no. 1, pp. 156-159, 1987.

[16] S. Hadj-Rabia, D. Oriot, N. Soufir et al., "Unexpected extradermatological findings in 31 -Xeroderma Pigmentosum type C patients," British Journal of Dermatology, vol. 168, no. 5, pp. 1109-1113, 2012.

[17] P. T. Bradford, A. M. Goldstein, D. Tamura et al., "Cancer and neurologic degeneration in xeroderma pigmentosum: long term follow-up characterises the role of DNA repair," Journal of Medical Genetics, vol. 48, no. 3, pp. 168-176, 2011.

[18] N. A. Bowden, K. A. Ashton, K. A. Avery-Kiejda, X. D. Zhang, P. Hersey, and R. J. Scott, "Nucleotide excision repair gene expression after cisplatin treatment in melanoma," Cancer Research, vol. 70, no. 20, pp. 7918-7926, 2010.

[19] T. Budden and N. A. Bowden, "The role of altered nucleotide excision repair and UVB-induced DNA damage in melanomagenesis," International Journal of Molecular Sciences, vol. 14, no. 1, pp. 1132-1151, 2013.

[20] M. L. Khatri, M. Bemghazil, M. Shafi, and A. Machina, "Xeroderma pigmentosum in Libya," International Journal of Dermatology, vol. 38, no. 7, pp. 520-524, 1999.

[21] S. Karger, K. Krause, C. Engelhardt et al., "Distinct pattern of oxidative DNA damage and DNA repair in follicular thyroid tumours," Journal of Molecular Endocrinology, vol. 48, pp. 193202, 2012.

[22] E. Conti and E. Izaurralde, "Nonsense-mediated mRNA decay: molecular insights and mechanistic variations across species," Current Opinion in Cell Biology, vol. 17, no. 3, pp. 316-325, 2005.

[23] R. U. Sidwell, A. Sandison, J. Wing et al., "A novel mutation in the XPA gene associated with unusually mild clinical features in a patient who developed a spindle cell melanoma," British Journal of Dermatology, vol. 155, no. 1, pp. 81-88, 2006.

[24] S. G. Khan, A. Metin, E. Gozukara et al., "Two essential splice lariat branchpoint sequences in one intron in a xeroderma pigmentosum DNA repair gene: mutations results in reduced XPC mRNA levels that correlate with cancre risk," Human Molecular Genetics, vol. 13, no. 3, pp. 343-352, 2004.

[25] L. Romdhane, R. Kefi, H. Azaiez, N. Ben Halim, K. Dellagi, and S. Abdelhak, "Founder mutations in Tunisia: implications for diagnosis in North Africa and Middle East," Orphanet Journal of Rare Diseases, vol. 7, pp. 1750-1172, 2012.

[26] M. Krawczak, D. N. Cooper, and J. Schmidtke, "Estimating the efficacy and efficiency of cascade genetic screening," American Journal of Human Genetics, vol. 69, no. 2, pp. 361-370, 2001.

[27] J. K. Morris, M. R. Law, and N. J. Wald, "Is cascade testing a sensible method of screening a population for autosomal recessive disorders?" American Journal of Medical Genetics A, vol. 128A, no. 3, pp. 271-275, 2004. 


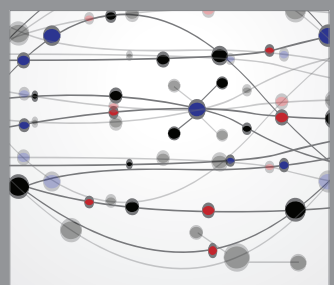

The Scientific World Journal
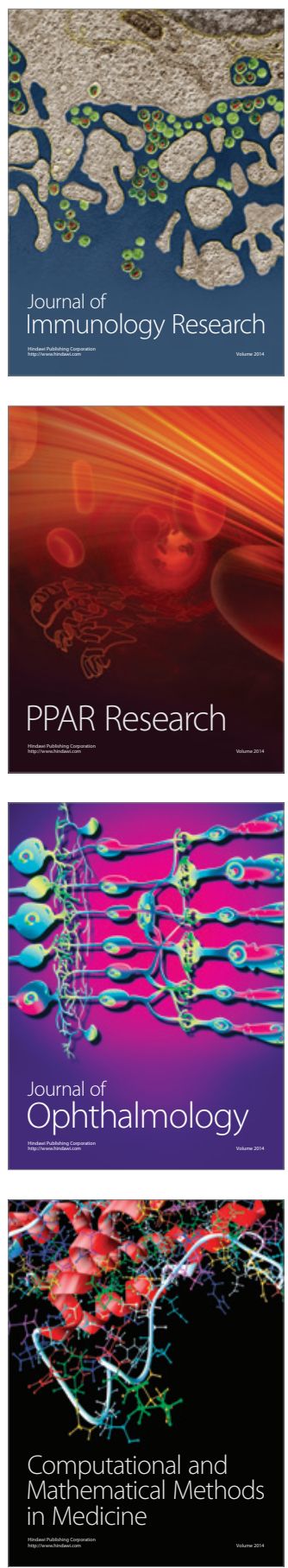

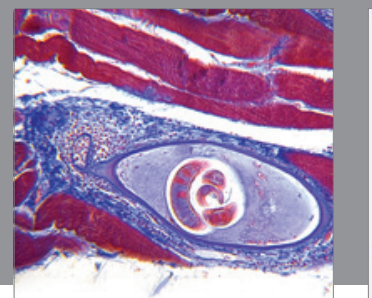

Gastroenterology

Research and Practice
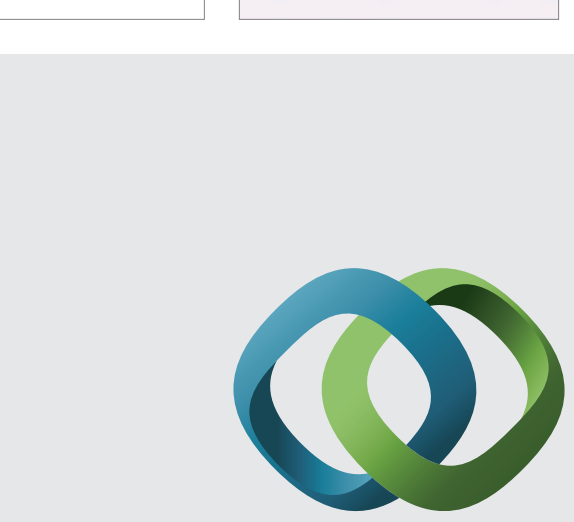

\section{Hindawi}

Submit your manuscripts at

http://www.hindawi.com
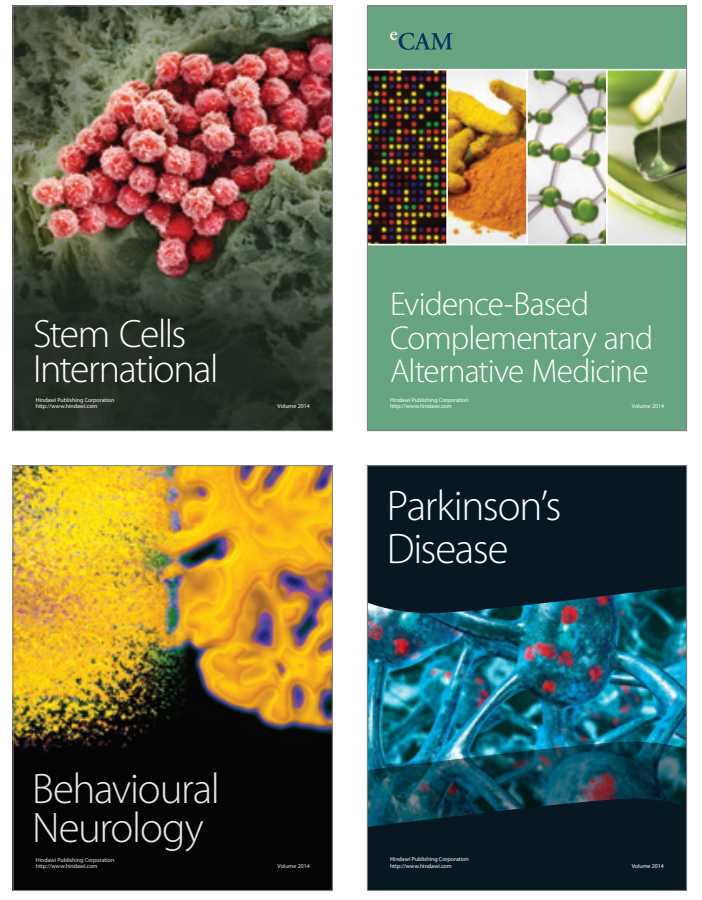
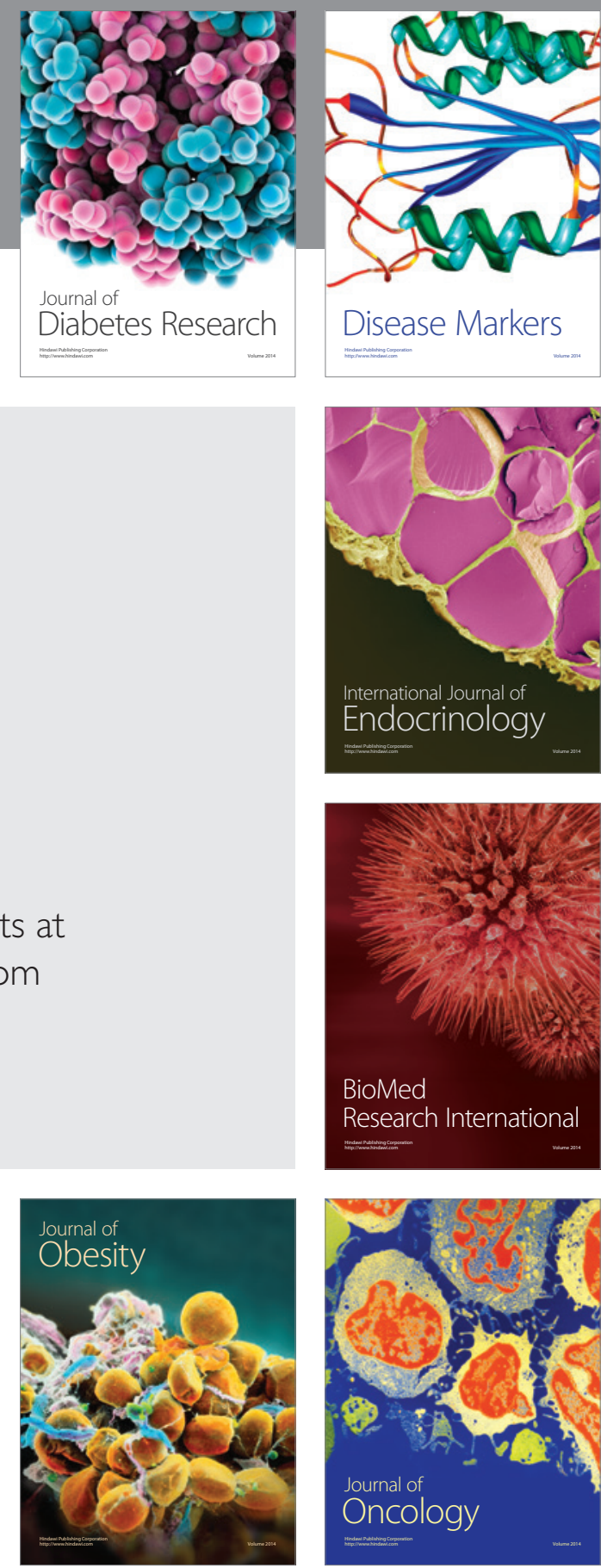

Disease Markers
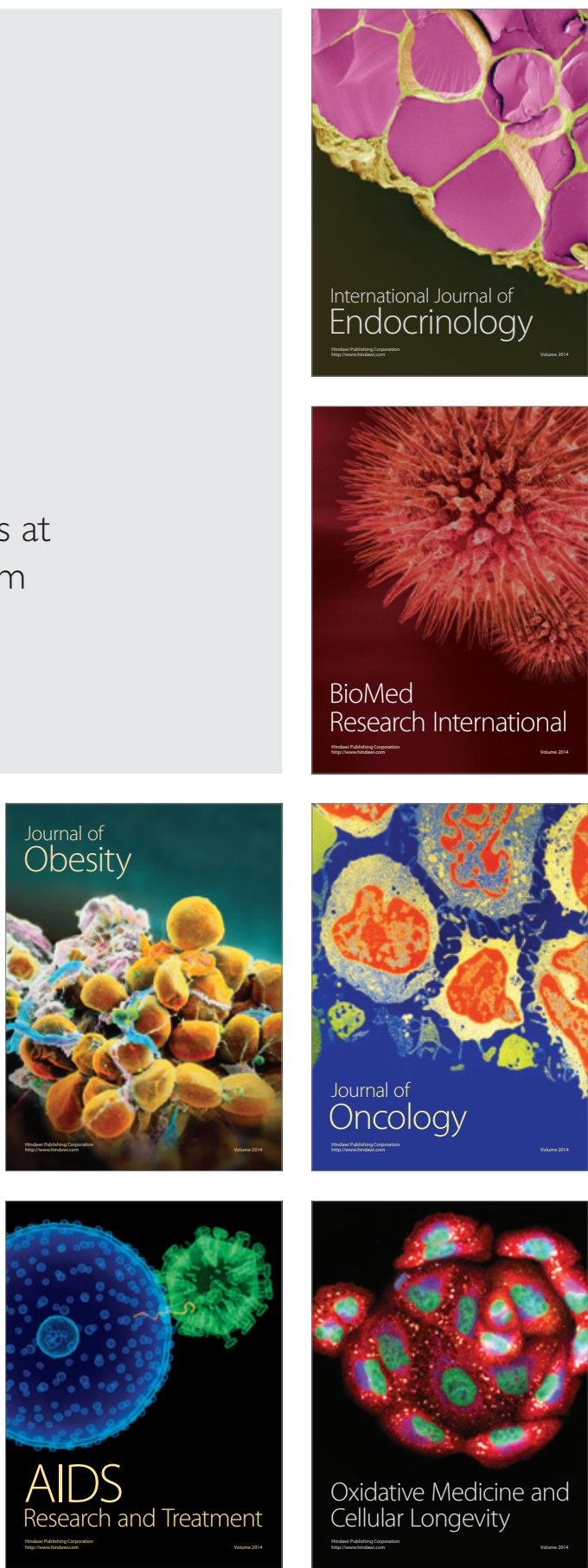